DOI: https://doi.org/10.32836/2521-666X/2019-66-5

УДК 339.13:004+330.366(477)

Турянський Ю.І. ${ }^{1}$

доктор економічних наук, доцент,

Львівський регіональний інститут державного

управління

Національної академії державного управління

при Президентові України

Свидрук I.I. ${ }^{2}$

доктор економічних наук, доцент,

Львівський торговельно-економічний університет

Клепанчук O.Ю. ${ }^{3}$

кандидат економічних наук, доцент,

Львівський національний університет

імені Івана Франка

\title{
Turyanskyy Yuriy
}

Lviv Regional Institute of Public Administration of the

National Academy of Public Administration

under the President of Ukraine

Svydruk Irena

Lviv University of Trade and Economic

Klepanchuk Olga

Ivan Franko National University of Lviv

\section{ДІДЖИТАЛІЗАЦІЯ ВНУТРІШНЬОГО РИНКУ УКРАЇНИ ЯК ІНСТРУМЕНТ ДОСЯГНЕННЯ ЦІЛЙ СТАЛОГО РОЗВИТКУ}

\section{DIZHITALIZATION OF THE INTERNAL MARKET OF UKRAINE AS A TOOL TO ACHIEVE SUSTAINABLE DEVELOPMENT GOALS}

У статті досліджено можсливості та пріоритети структурних змін внутрішнього ринку згідно із завданнями Цілей сталого розвитку ООН. Показано, щяо низька інвестиційна привабливість України гальмує модернізацію та знижує інновачійний потенціал економіки, щзо приводить до критичного зниження конкурентоздатності внутрішнього ринку. Розвиток иифрових технологій, інфраструктури та компетенцій визначено критичною точкою діджиталізаиії внутрішнього ринку. Інституційне реформування вітчизняного ринку має стратегічно орієнтуватись на недопущення критичних цифрових розривів з крайнами, що стабільно розвиваються в інновачійно-креативному векторі. Це прямо кореспондується із ЦСР щодо реалізації ринкового потенціалу та креативізаиії економіки, а інституційні зусилля, спрямовані на використання ефекту «иифрових дивідендів», дадуть внутрішньому ринку поштовх до високотехнологічного виробництва з високою доданою вартістю.

Ключові слова: інституиійне реформування ринку, ичифрові технологї̈, інновації, науковий потениіал, технологічний прорив, структура експорту.

${ }^{1}$ ORCID: https://orcid.org/0000-0002-4892-0653

${ }^{2}$ ORCID: https://orcid.org/0000-0002-3099-6449

${ }^{3}$ ORCID: https://orcid.org/0000-0001-7764-614X 
В статье исследованы возможности и приоритеты структурных изменений внутреннего рынка в соответствии с заданиями Целей устойчивого развития ООН. Показано, что низкая инвестиционная привлекательность Украины тормозит модернизацию и снижсает инновационный потенциал экономики, что приводит к критическому снижению конкурентоспособности внутреннего рынка. Развитие цифровых технологий, инфраструктуры и компетенций определено критической точкой диджитализации внутреннего рынка. Институчиональное реформирование отечественного рынка должно стратегически ориентироваться на недопущение критических цифровых разрывов со странами, стабильно развивающимися в инновационно-креативном векторе. Это прямо корреспондируется с ЦУР касательно реализации рыночного потенциала и креативизации экономики, а институциональные усилия, направленные на использование эффекта «иифровых дивидендов», дадут внутреннему рынку толчок к высокотехнологичному производству с высокой добавочной стоимостью.

Ключевые слова: институциональное реформирование рынка, ичифровые технологии, инновации, научный потенциал, технологический прорыв, структура экспорта.

The article is devoted to the analysis of opportunities and priorities of structural changes in the internal market with the tasks of the UN Sustainable Development Goals, which strategically orient the institutional reform of the market towards sustainability, innovative transformations and changes of the export model in favor of high value added products. Digitalization is fundamentally destroying the classic paradigm of economics. At the same time, the domestic market of Ukraine is affected by the destructive factors of long-term de-industrialization, the predominance of raw materials production, the decline of scientific potential, personnel losses, moral and physical deterioration of fixed assets. Providing export potential with low value-added products, high GDP materiality, low labor productivity critically reduces the competitiveness of the domestic market. The rapid change in the business environment necessitates the development of new instruments for institutional reform of the internal market, so the necessity of exploring the possibilities and prospects of its digitization and their alignment with the Sustainable Development Goals, adapted to Ukraine, is actualized. Based on existing information and communication technologies in the market space, digitization can have a stimulating effect on their development and expansion into traditional (physical-analogue) sectors of the internal market, transforming it from consumption to resource creation. Information flows that form the nucleus of the digital economy, capable of self-generation and providing the most complete electronic-communication interaction between business structures, stakeholders and government institutions. The digital revolution is profoundly changing the economic and social fabric of the internal market, creating powerful opportunities for their development. Institutional reform should focus strategically on avoiding critical digital gaps with countries that are steadily developing in the innovation vector. This directly corresponds with the CSW on market potential and economic creativity, and institutional efforts to leverage the "digital dividend" effect will give the domestic market a push to innovate and refocus on high-tech manufacturing. The result of total domestic market digitization should be the modernization breakthrough of the domestic economy and its entry into the conceptual perspectives of "smart production" of the fourth industrial revolution, which envisages the creation of inter-branch centers of technology, total development of digital competences and access to capital for innovative market segments.

Key words: institutional market reform, digital technologies, innovations, scientific potential, technological breakthrough, export structure.

Постановка проблеми. Потужний вплив технологічних змін на розвиток внутрішнього ринку проявляється стрімким пришвидшенням інноваційних зрушень в економічному просторі держави. Поява нових технологій, таких як штучний інтелект, робототехніка та блокчейн, особливо їх конвергенція, $є$ рушійною силою радикальних структурних змін ринку. Цифровізація сучасних ринків спричинила появу нових способів ведення бізнесу, які докорінно руйнують класичні парадигмальні засади економіки. Так, за останні
10 років лише 174 діджиталізовані стартапи спричинили появу надсучасних галузей із сукупною капіталізацією понад квінтильйона доларів США, і цей креативний ринок ламає стереотипність застарілих бізнес-моделей [16]. Наприклад, найпотужніші гравці інтернет-простору "Facebook" i “Twitter" не створюють власного контенту, найбільша роздрібна компанія "Alibaba" не має власних товарних запасів, найбільший оператор послуг таксі “Uber" не утримує власного автопарку. Стрімкі й часом непередбачувані 
зміни бізнес-середовища зумовлюють необхідність виникнення нових інструментів інституційного реформування всіх сегментів внутрішнього ринку та їх узгодження 3 адаптованими для України Цілями сталого розвитку [18]. Завдяки потужному науковому потенціалу сьогодні в Україні об'єктивно існують передумови для здійснення науково-технологічного стрибка, відкриваються реальні можливості для переходу вітчизняної економічної системи на високі технологічні рівні розвитку. Отож, дослідження можливостей та перспектив діджиталізації внутрішнього ринку України, визначення критичних сфер та узгодження проєктів цифровізації вітчизняної економіки $з$ цілями сталого розвитку України є дуже актуальним завданням. Надважливо для цього ефективно задіяти весь наявний потенціал інформаційно-комунікаційних і цифрових технологій, забезпечити активний розвиток і доступність інформаційної інфраструктури, системну інтеграцію високотехнологічних секторів внутрішнього ринку у світову економіку, акцентувати увагу на креативній складовій розвитку ринку праці.

Аналіз останніх досліджень і публікацій. Аналізу сучасного стану цифровізації вітчизняної економіки, виявленню основних тенденцій цього процесу та його впливу на макроекономічні показники були присвячені дослідження О. Даннікова, К. Січкаренко [3]. М. Диба, Ю. Гернего аналізували перспективи розвитку національної економіки з урахуванням потенціалу діджиталізації [5]. Зокрема, задля надання комплексної оцінки потенціалу діджиталізації вітчизняної економіки ними було проаналізовано недоліки та переваги використання інформаційно-комунікаційних технологій банками, представниками бізнесу, громадськими організаціями й закладами освіти. О. Грибіненко вивчав процеси діджиталізації під кутом зору трансформації, проникнення цифрових технологій у бізнес-процеси та їх впливу на підвищення продуктивності та покращення комунікаційної взаємодії зі споживачами [1]. С. Туль розглядав питання діджиталіза- ції зайнятості й запропонував класифікацію нових форм праці, які виникають під впливом швидкого розвитку цифрових технологій [12]. Н. Краус, О. Голобородько, К. Краус дослідили й узагальнили характерні особливі тренди цифрової економіки, запропонували напрями початкового етапу запровадження діджиталізації в Україні, такі як технологічні, виробничі та інституційно-економічні [8]. Дослідження "ManpowerGroup" [21] аргументовано доводять, що цифровізація змінює підходи до ведення бізнесу, а відповідні інституціональні зрушення мають ознаки перетворювальних процесів у соціально-економічному та авангардно-креативному розвитку всіх сегментів ринку. Водночас практично повністю відсутніми $\epsilon$ дослідження взаємовпливу та взаємообмежень діджиталізації ринкового простору та суспільно прийнятних пріоритетів досягнення цілей сталого розвитку.

Мета статті полягає в аналізі можливостей та пріоритетів структурних змін внутрішнього ринку із завданнями Цілей сталого розвитку ООН, які стратегічно орієнтують інституційне реформування ринку на стійкість, інноваційні перетворення та зміни експортної моделі на користь продуктів 3 високою доданої вартістю.

Виклад основного матеріалу. Необхідність термінового запровадження структурних змін та інституційних реформ на внутрішньому ринку України зумовлює пошук інструментів їх узгодження 3 орієнтирами досягнення Україною Цілей сталого розвитку (ЦСР), затверджених на Саміті ООН зі сталого розвитку у 2015 році. Національна система ЦСР, що включає 86 завдань національного розвитку та містить 172 моніторигових показники [10], побудована за принципом всеосяжного залучення всіх підсистем внутрішнього ринку для забезпечення надійного підгрунтя розвитку вітчизняної економічної системи. Сьогодні до вітчизняних умов розвитку внутрішнього ринку вважаються адаптованими адаптації 17 глобальних ЦСР, встановлено розрахунково-прогнозні бенчмаркінгові орієнтири до 2030 року, за 
допомогою сценарних підходів визначено напрями ринкового розвитку на довгострокову перспективу [6].

Впровадження інструментів структурних змін та інституційних реформ на внутрішньому ринку потребує чіткого визначення суспільно прийнятних пріоритетів досягнення цілей розвитку. Узгодження структурних змін із завданнями ЦСР (табл. 1) стратегічно орієнтує розвиток внутрішнього ринку України на стале економічне зростання, інституційне реформування та розбудову стійкості, вимагаючи переорієнтування вітчизняної економіки в бік інноваційного розвитку та зміни структури експорту від сировинної моделі до продуктів з високою доданої вартістю.

Розвиток внутрішнього ринку України тривалий час зазнає впливу деструктивних чинників довготривалої деіндустріалізації, переважання сировинного виробництва, зниження наукового потенціалу, кадрових втрат, морального й фізичного зносу основних засобів. Отже, експортний потенціал забезпечується здебільшого продукцією з низькою доданою вартістю, у технологічній структурі експорту України частка високотехнологічних товарів у 2018 році становила 6,2\% (рис. 1), тоді як у світі цей показник сягає 20\% [19].

Таблиця 1

Цілі та індикатори структурних змін на внутрішньому ринку України

\begin{tabular}{|c|c|c|c|c|c|}
\hline \multirow{2}{*}{ Цілі } & \multirow{2}{*}{ Індикатори } & \multicolumn{4}{|c|}{$\begin{array}{l}\text { Цільові значення } \\
\text { індикаторів }\end{array}$} \\
\hline & & $\begin{array}{c}2015 \\
\text { рік }\end{array}$ & $\begin{array}{l}2020 \\
\text { рік }\end{array}$ & $\begin{array}{c}2025 \\
\text { рік }\end{array}$ & $\begin{array}{c}2030 \\
\text { рік }\end{array}$ \\
\hline \multirow{4}{*}{$\begin{array}{l}\text { 1. Зростання ВВП на основі мо- } \\
\text { дернізації внутрішнього ринку, } \\
\text { розвитку інновацій, експортної } \\
\text { переорієнтації на продукцію } 3 \\
\text { високою доданою вартістю }\end{array}$} & $\begin{array}{l}1.1 \text { середньорічний індекс фізичного } \\
\text { обсягу ВВП, \% }\end{array}$ & 90,2 & 104 & 106 & 107 \\
\hline & 1.2 частка основного капіталу у ВВП, \% & 13,5 & 23 & 28 & 22 \\
\hline & $\begin{array}{l}1.3 \text { частка експорту високотехноло- } \\
\text { гічних товарів у загальному обсязі } \\
\text { експорту, \% }\end{array}$ & 19,2 & 25 & 28 & 30 \\
\hline & $\begin{array}{l}1.4 \text { позиції України у рейтингу Global } \\
\text { Innovation Index }\end{array}$ & 64 & 50 & 45 & 40 \\
\hline \multirow{3}{*}{$\begin{array}{l}\text { 2. Переорієнтація ринків на заса- } \\
\text { дах сталого розвитку та конку- } \\
\text { рентного високотехнологічного } \\
\text { виробництва }\end{array}$} & 2.1 коефіцієнт віддачі основних засобів & 0,23 & 0,26 & 0,35 & 0,45 \\
\hline & 2.2 продуктивність праці, \% & 99,1 & 104 & 103,6 & 105 \\
\hline & $\begin{array}{l}2.3 \text { матеріалоємність ВВП (відношення } \\
\text { обсягу проміжних витрат до загального } \\
\text { обсягу ВВП) }\end{array}$ & 0,88 & 0,87 & 0,82 & 0,77 \\
\hline $\begin{array}{l}\text { 3. Інституційне реформування } \\
\text { задля реалізації ринкового потен- } \\
\text { ціалу та креативізації економіки }\end{array}$ & $\begin{array}{l}3.1 \text { позиції України у рейтингу легкості } \\
\text { ведення бізнесу Doing Business }\end{array}$ & 81 & 30 & 25 & 20 \\
\hline \multirow{4}{*}{$\begin{array}{l}\text { 4. Прискорений розвиток за } \\
\text { ланцюгом «освіта - наука - ви- } \\
\text { робництво» таких високотехно- } \\
\text { логічних секторів внутрішнього } \\
\text { ринку: } \\
\text { - переробна промисловість; } \\
\text { - інформаційно-телекомуніка- } \\
\text { ційні технології; } \\
\text { - високотехнологічне машино- } \\
\text { будування; } \\
\text { - нові матеріали; } \\
- \text { фармацевтичний ринок; } \\
- \text { біоінженерний сектор. }\end{array}$} & $\begin{array}{l}4.1 \text { частка доданої вартості за витратами } \\
\text { високотехнологічних секторів внутріш- } \\
\text { нього ринку до загальної суми доданої } \\
\text { вартості за витратами виробництва, \% } \\
\end{array}$ & 1,9 & \multicolumn{3}{|c|}{ Дані очікуються } \\
\hline & $\begin{array}{l}4.2 \text { частка працівників, задіяних у } \\
\text { високотехнологічних секторах вну- } \\
\text { трішнього ринку, до загальної кількості } \\
\text { зайнятих в економіці працівників, \% } \\
\end{array}$ & 21 & 26 & 28 & 29 \\
\hline & $\begin{array}{l}4.3 \text { частка витрат на виконання науко- } \\
\text { вих і науково-технічних робіт у ВВП, \% }\end{array}$ & 0,62 & 1,5 & 2 & 3 \\
\hline & $\begin{array}{l}4.4 \text { частка реалізованої інноваційної } \\
\text { продукції в обсязі промислової, \% }\end{array}$ & 1,4 & 5 & 10 & 15 \\
\hline
\end{tabular}

Джерело: розраховано на основі даних джерела [10] 


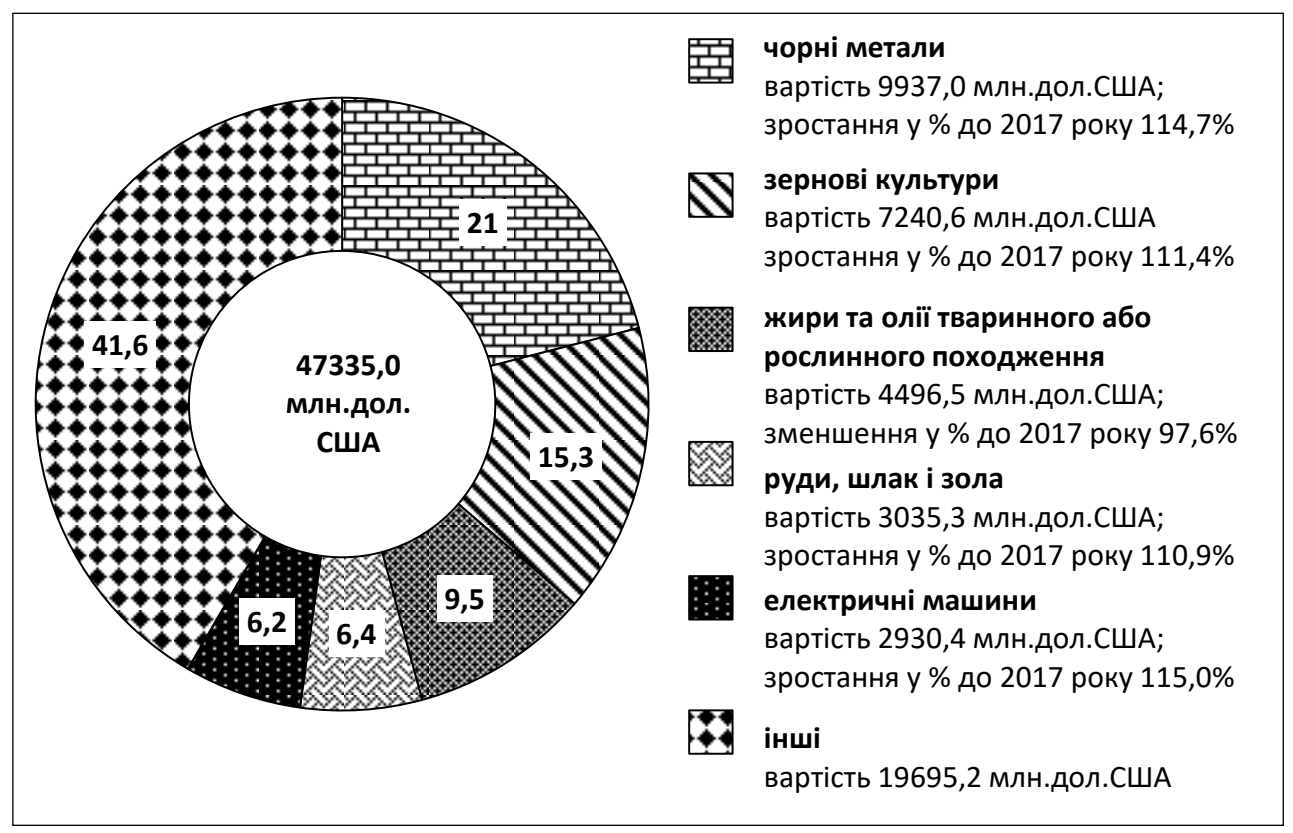

Рис. 1. Структура експорту товарів України у 2018 році, \% [4]

Низька інвестиційна привабливість внутрішнього ринку України, обмеженість доступу великої частки ринкових суб'єктів до фінансових ресурсів зумовлюють стабільно низький ступінь нагромадження валового капіталу в структурі ВВП (рис. 2). Практично не відбувається приросту активів внутрішнього ринку України, гальмується модернізація економіки, знижується інноваційний потенціал. Разом з високою матеріалоємністю ВВП $(0,881$ проти середньоєвропейського значення 0,44$)$ та низькою продуктивністю праці (17,2 тис. дол. США проти середньоєвропейського значення 30,5 тис. дол. США) це приводить до критичного зниження конкурентоздатності внутрішнього ринку України й не сприяє сталому зростанню вітчизняної економіки.

3 огляду на те, що інклюзивний стійкий розвиток внутрішнього ринку $є$ основним джерелом стабільної індустріалізації національної економіки [6], структурні змін та інституційні реформи мають концентруватись на досягненні цілей реалізації ринкового потенціалу та креативізації економіки.
За останні роки світова економічна спільнота означила шляхи інклюзивної та стабільної індустріалізації, запропонувавши іiі основним інструментом діджиталізацію економічного простору [19]. Структурні зміни внутрішнього ринку України передбачають створення ринкових стимулів та мотивацій для становлення цифрової економіки.

Чільне місце у трансформаційних процесах належить питанням запровадження цифрових технологій, розвитку цифрової інфраструктури та компетенцій. Саме ці аспекти визначають критичні точки стимулювання внутрішнього ринку щодо виробництва високотехнологічної продукції, сприяють зростанню його ефективності й конкурентоздатності. Запровадження цифрових технологій має інтегруватись не лише з цілями ЦУР для розвитку промисловості, інновацій та інфраструктури, але й $з$ інституційними механізмом сприяння інноваційним технологіям. Згідно з результатами досліджень Center for Creative Leadership саме цифровізація (діджиталізація) економічного простору здатна стати найголовнішим драйвером зростання 


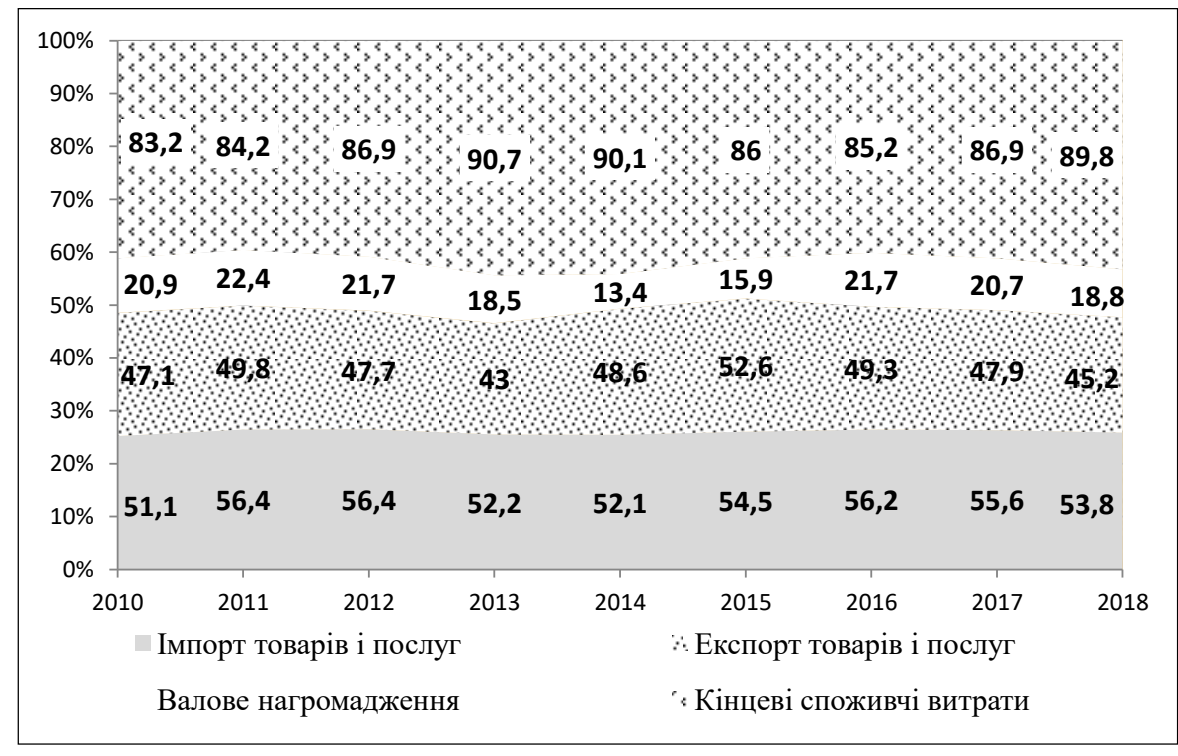

\section{Рис. 2. Структура ВВП \\ за категоріями кінцевого використання, \% до ВВП [4]}

у найближчій перспективі, адже іiі активне й успішне запровадження найтіснішим чином корелює з такими макроекономічними показниками, як зростання ВВП на душу населення й зниження рівня безробіття, а також ініціює різкий стрибок інноваційно-інвестиційної активності бізнес-середовища [16].

Базуючись на наявних у ринковому просторі інформаційно-комунікаційних технологіях, діджиталізація здатна чинити стимулюючий вплив на їх розвиток і поширення в традиційні (фізично аналогові) сектори внутрішнього ринку, трансформуючи його від споживання до створення ресурсів. Інформаційні потоки, які становлять ядро цифрової економіки, здатні до самогенерації та забезпечення найповнішої електронно-комунікаційнної взаємодії бізнес-структур, стейкхолдерів та державних інституцій.

Під час проведення High-Level Political Forum 2019 досліджувались способи взаємоузгодження розвитку світової цифрової економіки із ЦСР. Зокрема, зазначалось, що діджиталізація здатна мінімізувати нерівність громадян щодо отримання освітніх, соціальних, інформаційних послуг, може включатись до числа інституційних інструментів електронного урядування, системно покращувати управління інформаційними потоками [20]. Наприклад, широкосмуговий зв'язок може стати фактором підвищення рівня ринкових комунікацій та запобігання цифровій ізоляції окремих сегментів внутрішнього ринку, Blockchain володіє значним потенціалом досягнення проголошених ЦСР безпекових норм щодо харчових продуктів, мобільні технології забезпечують доступ до онлайн-інструментів управління та широких масивів відкритої інформації.

Цифрова революція глибоко змінює економіко-соціальну структуру внутрішніх ринків всіх держав, створює надпотужні можливості для їх розвитку. Однак темпи діджиталізації у світі є дуже нерівномірними, що зумовлює безпрецедентні виклики цифрових розривів між національними ринками. Отже, інституційне реформування вітчизняного ринку має стратегічно орієнтуватись на недопущення виникнення критичних цифрових розривів з країнами, що стабільно розвивають внутрішні ринки в інноваційно-креативному векторі. Це прямо кореспондується 
із ЦСР щодо реалізації ринкового потенціалу та креативізації економіки, а інституційні зусилля, спрямовані на використання ефекту «цифрових дивідендів», дадуть вітчизняному внутрішньому ринку поштовх до інноваційно-креативного стрибку та переорієнтації на високотехнологічне виробництво.

Основною метою інтегрування державної стратегії діджиталізації у ринковий простір України є досягнення цифрової трансформації його наявних сегментів і створення інноваційно-креативних ринкових секторів. Цифрові технології можна розглядати як сучасний феноменологічний об'єкт економічної системи, що поєднує властивості й характеристики окремого сегменту ринку, ознаки самостійної галузі та відіграє роль визначника конкурентоспроможності й стимулятора ефективності для інших галузей діяльності та ринкових сегментів. Це означає, що вони мають бути покладені в підгрунтя системного інституційного реформування 3 використанням усіх наявних можливостей для модернізації наявних сегментів внутрішнього ринку й стимулювання високотехнологічного виробництва.

Орієнтація запровадження цифрових технологій на внутрішньому ринку України на системне досягнення ЦСР вимагає, щоб основні зусилля діджитилізації спрямовувались на виконання таких завдань сприяння всеохоплюючому та сталому економічному зростанню:

- економічний прорив та активізація інвестиційної активності;

- трансформація наявних сегментів внутрішнього ринку в конкурентоспроможні та високоефективні;

- технологічна й креативна модернізація промислових суб' єктів внутрішнього ринку;

- розвиток людських ресурсів, їх інноваційного та креативного потенціалу й компетенцій.

Дослідження потенціалу діджиталізації стосовно досягнення ЦУР показує, що цифрові технології здатні інтегрувати в єдиний інформаційний простір виробничі процеси різних сегментів внутрішнього ринку. Це зумовлює виникнення інституційних можливостей щодо більш узгодженого реформування внутрішнього ринку з урахуванням моделей цілісного управління його розвитком шляхом активізації інновацій, цифровізації та креативних технологій, особливо інформаційних та комунікаційних.

Діджиталізація внутрішнього ринку має забезпечувати цифрову підтримку інституційних механізмів зростання й трансформації внутрішнього ринку через зростання продуктивності виробничо-господарських процесів та конкурентоздатності всіх сегментів ринку внаслідок використання цифрових технологій. Цим інструментом передбачається набуття внутрішнім ринком нових конкурентних якостей через всеосяжне перетворення наявної в Україні аналогової соціально-економічної системи у революційний цифровий формат, здатний стати трансформаційним ядром створення нових робочих місць і формування оновлених тенденцій інвестиційного пожвавлення.

Орієнтуючи внутрішній ринок до міжнародного співробітництва, діджиталізація завдяки приведенню внутрішніх норм і стандартів до світових норм, глобальних систем та інфраструктур здатна стати значним важелем прискорення євроінтеграційних процесів України й виходу іiі внутрішнього ринку на світовий ринок, особливо ринок інформаційно-комунікаційних та цифрових технологій.

Щодо розвитку інформаційних інфраструктур як основного інструменту діджиталізації внутрішнього ринку України, на жаль, можна говорити про вже наявний цифровий розрив. Задля його подолання й для реалізації нових можливостей розвитку внутрішнього ринку сьогодні розробляються національні твердо-цифрові інфраструктурні платформи, що включають теле-, радіо-, широкосмугову фіксовану й мобільну телекомунікації, інфраструктуру віртуалізації та збереження хмарних і туманних даних, доповненої реальності, предиктивної аналітики, штучного інтелекту, кібербезпеки тощо. М'які цифрові інфраструктури включають забезпечення проєктів ідентифікації, відкритих даних, 
електронних транзакцій та онлайн-взаємодії стейкхолдерів, а також блокчейн та електронне урядування.

Діджиталізація внутрішнього ринку $\epsilon$ головним важелем становлення цифрової економіки в Україні, визначає шляхи не лише розвитку цифрових індустрій, але й соціально-економічної перебудови загалом. Інституційне реформування й трансформація традиційних моделей бізнесу, виробничих ланцюгів та операційних процесів вимагають і зумовлюють виникнення концептуально нових товарів і послуг, спричиняють появу інноваційних бізнес-платформ і секторів ринку, що прямо кореспондується 3 досягненням цілей ЦСР прискореного розвитку високотехнологічних секторів внутрішнього ринку.

Водночас не можна обійти той факт, що національна інтерпретація окремих ЦСР, запропонована Міністерством економічного розвитку і торгівлі України, викликає сумніви щодо ефективності застосування інструментів інституційних реформ на внутрішньому ринку в означеному ракурсі. Зокрема, одна 3 найважливіших економічних субцілей в загальній інтерпретації ООН спрямована на підвищення продуктивності економіки шляхом диверсифікації, технічної модернізації та інноваційної діяльності з прицільною увагою до секторів 3 високою доданою вартістю й наукоємним виробництвом [18]. Натомість національне визначення оперує категоріями стійкого зростання ВВП на основі модернізації виробництва й розвитку інновацій, а також зростання експортного потенціалу внутрішнього ринку через його структурну зміну в бік продукції з високою часткою доданої вартості [10]. Як бачимо, границі субцілі значно звужено, що дезорганізовує розроблення інституційних важелів здійснення високотехнологічного прориву в неекспортноорієнтованих секторах ринку.

Для досягнення цієї мети необхідно розробити стратегію модернізації промислового комплексу, яка би враховувала національні та глобальні виклики (ресурсні, інституційні, соціально-економічні тощо) діджиталізації внутрішнього ринку. Стратегія має базуватись на положеннях Угоди про поглиблену всеохоплюючу зону вільної торгівлі з $\mathrm{CC} \mathrm{і}$ створювати умови для використання європейських програм «Розумні спеціалізації», «Горизонт 2020», «Європейська кластерна програма». Формування нової структури внутрішнього ринку й визначення напрямів його диверсифікації та кластеризації вимагають розроблення та запровадження інституційних важелів та інструментів розумних спеціалізацій [10] з урахуванням їх впливу на зростання частки продукції з високою доданою вартістю. Інституційне реформування ринку має інтегрувати принципи ділової досконалості та управління якістю на всіх рівнях (макро-, мезо- та мікро-) для підвищення конкурентоспроможності національної економіки.

Розвиток людського капіталу стає в таких умовах інструментом забезпечення ефективності діджиталізації. Робочі місця, більше не прив'язані до фізичних координат, набувають чітких рис віртуальності й значно розширюють можливості віддаленої роботи. Водночас віртуалізація дає змогу значно скоротити затрати на обслуговування робочих місць. Цифрові робочі місця, однак, висувають нові вимоги до якості віртуалізованого персоналу. На перші позиції висуваються вимоги щодо гнучкості, ефективної взаємодії, децентралізації та мобільності. Дуже високі вимоги мають висуватись і до рівня професійної компетенції діджиталізованого персоналу, його самодисципліни, креативності та здатності до безперервного саморозвитку й професійного самовдосконалення.

Висновки. Результатом тотальної діджиталізації внутрішнього ринку має стати модернізаційний прорив вітчизняної економіки й вихід іiі на концептуальні перспективи «розумного виробництва» четвертої промислової революції, що передбачає створення міжгалузевих центрів технологій, тотальний розвиток цифрових компетенцій та доступ до капіталу для інноваційних сегментів ринку. Необхідно зосередити подальші дослідження на позитивних та негативних наслідках 
швидких технологічних змін внутрішнього ринку щодо прогресу стосовно досягнення ЦСР. Системні зміни діджиталізації високотехнологічних сегментів ринку в умовах глибоких трансформацій економічного простору потребують внутрішньодержавного інститу- ційного регулювання та посилення співробітництва 3 міжнародними інституціями щодо нарощування інноваційного потенціалу та обміну інформаційними потоками для відповідального впровадження нових технологій, уникаючи обмеження ЦСР щодо інновацій.

\section{Список літератури:}

1. Грибіненко О. Діджиталізація економіки в новій парадигмі цифрової трансформації. Міжнародні відносини. Серія «Економічні науки». 2018. № 16. С. 35-37.

2. Гусєва О., Легомінова С. Діджиталізація як інструмент удосконалення бізнес-процесів, їх оптимізація. Економіка. Менеджмент. Бізнес. 2018. № 1. С. 33-39.

3. Данніков О., Січкаренко К. Концептуальні засади цифровізації економіки України. Економіка та управління національним господарством. 2018. Вип. 17. С. 73-79.

4. Україна в цифрах 2018 : статистичний збірник / Державна служба статистики України. Київ, 2019. 45 с.

5. Диба М., Гернего Ю. Діджиталізація економіки: світовий досвід та можливості розвитку в Україні. Фінанси України. 2018. № 7. С. 50-63.

6. Про схвалення Концепції розвитку цифрової економіки та суспільства України на 2018-2020 роки та затвердження плану заходів щодо ії реалізації : Розпорядження від 17 січня 2018 року № 67-р / Кабінет Міністрів України. Офіційний вісник Украӥни. 2018. № 16. С. 70. Ст. 560. Код акта 89147/2018.

7. Краус Н., Голобородько О., Краус К. Цифрова економіка: тренди та перспективи авангардного характеру розвитку. Ефективна економіка. 2018. № 1. URL: http://www.economy. nayka.com.ua/pdf/1_2018/8.pdf (дата звернення: 15.11.2019).

8. Криворучко О., Краус Н., Краус К. «Ннноваційний портрет» європейського економічного простору. Інфраструктура ринку. 2017. № 3. С. 5-10.

9. Криворучко О., Краус Н. Імперативи формування та домінанти розвитку цифрової економіки у сучасному парадигмальному контексті. Парадигмальні зрушення в економічній mеорї XIX cm. : матеріали III Міжнародної науково-практичної конференції (2-3 листопада 2017 року). Київ : КНУ ім. Т. Шевченка, 2017. С. 681-685.

10. Цілі Сталого розвитку. Україна : національна доповідь / Міністерство економічного розвитку і торгівлі України. 2017. URL: https://SDGs_NationalReportUA_Web.pdf (дата звернення: 18.11.2019).

11. Паньшин Б. Цифровая экономика: особенности и тенденции развития. Наука и инновациии. 2016. № 157. С. 17-20.

12. Туль С. Нові форми праці в умовах діджиталізації економіки та світового ринку праці. Науковий вісник Ужгородського національного університету. 2019. Вип. 23. Ч. 2. С. 100-105.

13. Куприяновский В. и др. Целостная модель трансформаци в цифровой экономике как стать цифровыми лидерами. International Journal of Open Information Technologies. 2017. Vol. 5. No. 1. P. 26-33.

14. Bart V. The Productivity Paradox of the New Digital Economy. International Productivity Monitor. 2016. № 3. P. 31-42.

15. Creative Crowdsourcing Leader eYeka Releases 2017 Industry Report and Welcomes the Age of Ideation. The official website of eYeka. URL: http://news.eyeka.net/2017/06/creativecrowdsourcing-leader-eyeka-releases-2017-industry-report-and-welcomesthe-age-of-ideation (дата звернення: 18.11.2019).

16. Center for Creative Leadership. Digital Transformation Readiness Survey Summary. URL: https://www.ccl.org/wp-content/uploads/2018/04/Digital-Transformation-Survey-Report.pdf (дата звернення: 15.11.2019). 
17. The age of digital interdependence. Report of the UN Secretary-General's High-level Panel on Digital Cooperation. URL: https://www.un.org/en/pdfs/DigitalCooperation-report-for\%20web. $\operatorname{pdf}$ (дата звернення: 19.11.2019).

18. UN. Transforming our world: the 2030 Agenda for Sustainable Development. URL: http://www.un.org.ua/en/publications-and-reports/global-un-publications/4337-transforming-ourworld-the-2030-agenda-for-sustainable-development-2015 (дата звернення: 21.11.2019).

19. UNIDO Centre for International Industrial Cooperation. Industrial Upgrading and Modernization Programme. URL: https://www.unido.org/our-focus/advancing-economiccompetitiveness/industrial-upgrading-and-modernization-programme-iump (дата звернення: 21.11.2019).

20. UNSDG. Sustainable Development. High-Level Political Forum 2019 Under the auspices of ecosoc. URL: https://sustainabledevelopment.un.org/dsd_aofw_ind/index.php?menu=4749 (дата звернення: 21.11.2019).

21. Workforce Solutions of ManpowerGroup. The official website of ManpowerGroup. URL: https://www.manpowergroup.com/ workforce-solutions (дата звернення: 15.11.2019).

\section{References:}

1. Hrybinenko O. (2018). Didzhytalizatsiia ekonomiky v novii paradyhmi tsyfrovoi transformatsii [Digitizing the economy in the new paradigm of digital transformation]. International Relations. Series "Economic Sciences", vol. 16, pp. 35-37.

2. Husieva O., Lehominova S. (2018). Didzhytalizatsiia yak instrument udoskonalennia biznesprotsesiv, yikh optymizatsiia [Digitization as a tool for improving business processes, optimizing them]. Economy. Management. Business, 1, 33-39.

3. Dannikov O., Sichkarenko K. (2018). Kontseptualni zasady tsyfrovizatsii ekonomiky Ukrainy [Conceptual bases of digitalization of economy of Ukraine]. National Economy and Management, $17,73-79$.

4. State Statistics Service of Ukraine. (2019). Ukraina v tsyfrakh 2018. Statystychnyi zbirnyk [Ukraine in numbers 2018. Statistical compilation]. Kyiv. 45 p.

5. Dyba M., Herneho Yu. (2018). Didzhytalizatsiia ekonomiky: svitovyi dosvid ta mozhlyvosti rozvytku v Ukraini [Economic Digitization: Global Experience and Development Opportunities in Ukraine]. Finance of Ukraine, 7, 50-63.

6. The Cabinet of Ministers of Ukraine. (2018). Rozporiadzhennia Pro skhvalennia Kontseptsii rozvytku tsyfrovoi ekonomiky ta suspilstva Ukrainy na 2018-2020 roky ta zatverdzhennia planu zakhodiv shchodo yii realizatsii [On approval of the Concept of development of the digital economy and society of Ukraine for 2018-2020 and approval of the plan of measures for its implementation]. Official Gazette of Ukraine, no. 16, act code 89147/2018.

7. Kraus N., Holoborodko O., Kraus K. (2018) Digital Economy: Trends and Perspectives on the Advanced Nature of Development. An efficient economy. Available at: http://www.economy.nayka.com.ua/pdf/1_2018/8.pdf (accessed: 15.11.2019).

8. Kryvoruchko O., Kraus N., Kraus K. (2017). "Innovatsiinyi portret" yevropeiskoho ekonomichnoho prostoru ["Innovative portrait" of the European economic space]. Market infrastructure, 3. Available at: http://market-infr.od.ua/uk/3-2017 (accessed: 15.11.2019).

9. Kryvoruchko O., Kraus N. (2017). Imperatyvy formuvannia ta dominanty rozvytku tsyfrovoi ekonomiky u suchasnomu paradyhmalnomu konteksti [Formative imperatives and dominants of digital economy development in contemporary paradigm context]. Proceedings of the Paradigm Shifts in Economic Theory of the Nineteenth Century: 3rd International Scientific and Practical Conference (Kyiv, November 2-3, 2017), Kyiv : Kyiv National University, pp. 681-685.

10. Ministry of Economic Development and Trade of Ukraine. (2017). Tsili Staloho rozvytku: Ukraina. Natsionalna dopovid 2017 [Sustainable Development Goals: Ukraine. National Report 2017]. Available at: https://SDGs_NationalReportUA_Web.pdf (accessed: 18.11.2019).

11. Pan'shin B. (2016). Tsifrovaya ekonomika: osobennosti i tendentsii razvitiya [Digital Economy: Features and Trends in Development]. Science and Innovation, 157, 17-20. 
12. Tul S. (2019). Novi formy pratsi v umovakh didzhytalizatsii ekonomiky ta svitovoho rynku pratsi [New forms of labor in the context of digitization of the economy and the world labor market]. Uzhgorod National University Scientific Bulletin, 23 (2), 100-105.

13. Kupriyanovskiy V., Dobrynin A., Sinyagov S., Namiot D. (2017). Tselostnaya model' transformatsi $\mathrm{v}$ tsifrovoy ekonomike - kak stat' tsifrovymi liderami [The holistic transformation model in the digital economy is how to become a digital leader]. International Journal of Open Information Technologies, 5 (1), 26-33.

14. Bart V. (2016). The Productivity Paradox of the New Digital Economy. International Productivity Monitor, no. 3, 31-42.

15. Creative Crowdsourcing Leader eYeka. (2017). Releases 2017 Industry Report and Welcomes the Age of Ideation. The official website of eYeka. Available at: http://news.eyeka.net/2017/06/ creative-crowdsourcing-leader-eyeka-releases-2017-industry-report-and-welcomesthe-age-ofideation (accessed: 18.11.2019).

16. Center for Creative Leadership. (2018). Digital Transformation Readiness Survey Summary. Available at: https://www.ccl.org/wp-content/uploads/2018/04/Digital-Transformation-SurveyReport.pdf (accessed: 15.11.2019).

17. The age of digital interdependence. (2018). Report of the UN Secretary-General's High-level Panel on Digital Cooperation. Available at: https://www.un.org/en/pdfs/DigitalCooperation-reportfor\%20web.pdf (accessed: 19.11.2019).

18. UN.(2015). Transforming our world: the 2030. Agenda for Sustainable Development. Available at: http://www.un.org.ua/en/publications-and-reports/global-un-publications/4337-transformingour-world-the-2030-agenda-for-sustainable-development-2015 (accessed: 21.11.2019).

19. UNIDO Centre for International Industrial Cooperation (2018). Industrial Upgrading and Modernization Programme (IUMP). Available at: https://www.unido.org/our-focus/advancingeconomic-competitiveness/industrial-upgrading-and-modernization-programme-iump (accessed: 21.11.2019).

20. UNSDG. Sustainable Development. (2019). High-Level Political Forum 2019 Under the auspices of ecosoc. Available at: https://sustainabledevelopment.un.org/dsd_aofw_ind/index. php?menu=4749 (accessed: 21.11.2019).

21. Workforce Solutions of ManpowerGroup. (2018). The official website of ManpowerGroup. Available at: https://www.manpowergroup.com/ workforce-solutions (accessed: 15.11.2019). 